\title{
Genetic Diversity of Snap Bean Cultivars Determined Using Randomly Amplified Polymorphic DNA (RAPD) Markers
}

\author{
Claudia Cunha, Tana Hintz, and Phillip Griffiths ${ }^{1}$ \\ Department of Horticultural Sciences, Cornell University New York State \\ Agricultural Experiment Station, Geneva NY 14456
}

Additional index words. Phaseolus vulgaris, molecular markers

\begin{abstract}
DNA extractions from 77 snap bean and 2 dry bean cultivars were evaluated for molecular polymorphisms. In total, 10010 -mer oligonuceotide primers were evaluated, and 31 primers that amplified clear and repeatable polymorphisms among bean cultivars were selected. These primers amplified a total of 49 polymorphisms between the cultivars and were used to differentiate the cultivars and evaluate the genetic diversity between them. All cultivars were clustered according to genetic similarities using GenStat 5.0 software, and groupings of pod types were observed when cultivars were separated based on a dissimilarity index. The RAPD polymorphisms will be useful for cultivar determination, seed purity testing and estimation of genetic distances.
\end{abstract}

Received for publication 7 Apr. 2003. Accepted for publication 18 Aug. 2003.

${ }^{1}$ To whom reprint requests should be addressed; e-mail pdg8@cornell.edu.
Common bean (Phaseolus vulgaris L.) is one of the most widely cultivated legumes worldwide. They are harvested fresh as snap beans or as dry bean crops. Most snap beans and some dry beans originate from Andean
(Chile, Peru, Nueva Granada) areas of domestication, while most dry bean types have a Middle America (Jalisco, Durango, MesoAmerica) area of domestication (Gepts et al., 1986). These types can be determined based on phaseolin seed protein when separated by SDS polyacrylamide gel electrophoresis (Koenig et al., 1990). Common beans of Andean origin are characterized as T-, C-, $\mathrm{H}$ - and A-types, while beans of Middle America origin are Sand B-types (Gepts et al., 1986; Singh et al., 1991). Snap beans are marketed under different classes that include large sieve green beans, yellow/golden wax beans, flat podded romano beans and small sieve whole beans. The genetic diversity of common beans has previously been investigated, but has focused primarily on dry bean market classes (Beebe et al., 1995; Metais et al., 2000; Skroch et al., 1998). Investigation of genetic similarities among cultivars within or between market classes can help to determine variety identification (Graham etal., 1994), variability between gene pools (Haley et al., 1994; Johns et al., 1997), pedigree (Alzate-Marin et al., 1996), and choice of parents to maximize genetic distance (Machado et al., 2000).

Genetic diversity between common bean cultivars has been estimated using several types of molecular markers including RAPD, restriction fragment length polymorphisms

Table 1. Source and pod type of common bean cultivars used to determine genetic diversity

\begin{tabular}{|c|c|c|c|c|c|}
\hline Cultivar & Source & Type & Cultivar & Source & Type \\
\hline Acclaim & Seminis & $\mathrm{gb}^{\mathrm{z}}$ & Moncayo & Seminis & $\mathrm{rb}$ \\
\hline Amboto & Syngenta & $\mathrm{gb}$ & Marseille & Harris Moran & wb \\
\hline Aurora & Zwaan & $\mathrm{db}$ & Masai & Syngenta & wb \\
\hline Baby Bop & Seminis & wb & Medinah & Syngenta & wb \\
\hline Beany Baby & Seminis & $w b$ & Mercury & Syngenta & $\mathrm{gb}$ \\
\hline Bench Mark & Syngenta & $\mathrm{gb}$ & Minuette & Harris Moran & $\mathrm{gb}$ \\
\hline Benton & Syngenta & $\mathrm{gb}$ & Mirada & Syngenta & $\mathrm{gb}$ \\
\hline Blue Crop & Harris Moran & $\mathrm{gb}$ & Nicelo & Seminis & $\mathrm{gb}$ \\
\hline Bonanza & Seminis & $\mathrm{gb}$ & Normandie & Harris Moran & wb \\
\hline Brio & Seminis & $\mathrm{gb}$ & Opus & Seminis & $\mathrm{gb}$ \\
\hline Calgreen & Syngenta & $\mathrm{gb}$ & Pix & Seminis & wb \\
\hline Capricorn & Syngenta & $\mathrm{gb}$ & Podsquad & Seminis & $\mathrm{gb}$ \\
\hline Castano & Syngenta & $\mathrm{gb}$ & Probe & Harris Moran & $\mathrm{gb}$ \\
\hline Celtic & Syngenta & wb & Producer & Harris Moran & $\mathrm{gb}$ \\
\hline Charon & Syngenta & $\mathrm{gb}$ & Prosperity & Harris Moran & $\mathrm{gb}$ \\
\hline Conella & Syngenta & $\mathrm{gb}$ & Rhapsody & Harris Moran & $\mathrm{gb}$ \\
\hline Crest & Seminis & $\mathrm{gb}$ & Roma II & Syngenta & $\mathrm{rb}$ \\
\hline Dandy & Syngenta & $w b$ & Romano & Harris Moran & $\mathrm{gb}$ \\
\hline Daytona & Harris Moran & $\mathrm{gb}$ & Seafarer & Michigan St.U & $\mathrm{db}$ \\
\hline Derby & Harris Moran & $\mathrm{gb}$ & Seville & Syngenta & $\mathrm{gb}$ \\
\hline Earlybird & Maffeet Seed & $\mathrm{gb}$ & Shade & Harris Moran & $\mathrm{gb}$ \\
\hline Envy & Harris Moran & $\mathrm{gb}$ & Slenderette & Syngenta & wb \\
\hline Espada & Harris Moran & $\mathrm{gb}$ & Slenderwhite & Syngenta & wb \\
\hline Flevoro & Seminis & $\mathrm{wb}$ & Slimgym & Syngenta & wb \\
\hline Flo & Seminis & $\mathrm{gb}$ & Sonata & Harris Moran & $\mathrm{gb}$ \\
\hline Fury & Seminis & $\mathrm{gb}$ & Sprite & Seminis & $\mathrm{gb}$ \\
\hline Gator Green & Harris Moran & $\mathrm{gb}$ & Stretch & Seminis & $\mathrm{gb}$ \\
\hline Gold Mine & Seminis & WX & Summit & Syngenta & $\mathrm{gb}$ \\
\hline Golden Rod Wax & Harris Moran & wX & Sunburst & Seminis & $w x$ \\
\hline Hercules & Seminis & $\mathrm{gb}$ & Symphony & Harris Moran & $\mathrm{gb}$ \\
\hline Hialeah & Harris Moran & $\mathrm{gb}$ & Tapia & Seminis & $\mathrm{gb}$ \\
\hline Hystyle & Harris Moran & $\mathrm{gb}$ & Tenderlake & Harris Moran & $\mathrm{gb}$ \\
\hline Igloo & Pure Line & $\mathrm{gb}$ & Teseo & Syngenta & $\mathrm{gb}$ \\
\hline Indy Gold & Syngenta & wX & Titan & Seminis & $\mathrm{gb}$ \\
\hline Jade & Syngenta & $\mathrm{gb}$ & Trueblue & Harris Moran & $\mathrm{gb}$ \\
\hline Labrador & Seminis & $\mathrm{gb}$ & Valiant & Syngenta & $\mathrm{gb}$ \\
\hline Laureat & Seminis & $w b$ & Vitagreen & Syngenta & $\mathrm{gb}$ \\
\hline Leon & Syngenta & $\mathrm{gb}$ & Yukon & Pop Vriend & wx \\
\hline Legion & Seminis & $\mathrm{gb}$ & Zeus & Seminis & $\mathrm{gb}$ \\
\hline Majestic & Syngenta & wx, wb & & & \\
\hline
\end{tabular}

${ }^{\mathrm{z}} \mathrm{wb}=$ Whole bean, $\mathrm{wx}=$ wax bean, $\mathrm{rb}=$ romano bean, $\mathrm{db}=$ dry bean, $\mathrm{gb}=$ green bean. 
(RFLPs), sequence characterized amplified regions (SCARs), amplified fragment length polymorphisms (AFLPs), and simple sequence repeats (SSRs)/microsatellites (Bartish et al., 2000; Bautista et al., 2002; Gaitan-Solis et al., 2002; Lu et al., 1997; Steiger et al., 2002). Molecular markers can generate important information for germplasm clarification, cultivar identity, pedigree relationships and seed purity. The use of RAPD markers (Davis and Myers, 2002; Skroch et al., 1992;) is preferable as the relative cost is low and the availability of SCARs, SSRs, and expressed sequence tags (ESTs) for $P$. vulgaris is limited.

The evaluation of RAPD marker polymorphisms among snap bean cultivars is important for determining dissimilarities between the different classes of snap bean, and characterizing genetic variability among snap bean cultivars in general. In this study, we evaluated RAPD marker data to characterize snap bean cultivars with respect to genetic similarity and provide a molecular basis for variety identification of snap beans.

\section{Materials and Methods}

Germplasm. 77 snap bean cultivars and two dry bean cultivars ('Aurora' and 'Seafarer') were included in this study (Table 1). The cultivars included two romano bean cultivars, six wax bean cultivars, two dry bean cultivars, and 14 whole bean cultivars. The remaining 55 cultivars were considered to be large sieve, green bean types. All beans were planted in 32-cell (125$\mathrm{cm}^{3}$ ) Styrofoam trays ('Speedling', Sun City, Fla.) in 'Cornell Mix' (Boodley and Sheldrake, 1982) with one seed per cell on 1 July 2002. Plants were grown to the first trifoliate, which was removed for genomic DNA extraction 14 $\mathrm{d}$ after planting. The cultivars were grown in a greenhouse at $23 / 20{ }^{\circ} \mathrm{C}$ day/night with a 14 -h photoperiod under 1000-W metal halide lamps $\left(300 \mu \mathrm{mol} \cdot \mathrm{m}^{-2} \cdot \mathrm{s}^{-1}\right)$.

DNA procedures. DNA was extracted and bulked from the terminal leaflets of the first trifoliate leaf of four plants for each cultivar (Doyle and Doyle, 1990). DNA pellets were resuspended in $500 \mu \mathrm{L}$ of T.E. (10 mM Tris$\mathrm{HCl}, 0.1 \mathrm{~mm}$ EDTA, $\mathrm{pH}$ 8.0) and stored at -20 ${ }^{\circ} \mathrm{C}$. Random fragments of DNA were amplified using single, 10-mer, oligonucleotide primers (Biotechnology Lab., University of British Columbia, Vancouver, B.C.), in a modified polymerase chain reaction (PCR) buffer $(0.5 \mathrm{M}$ Tris $\mathrm{pH} 8.3,10 \mathrm{~mm} \mathrm{MgCl}_{2}, 10 \mathrm{~mm}$ Tartrazine, $14 \% \mathrm{w} / \mathrm{v}$ Ficoll). RAPD polymorphisms were generated using standard PCR procedures (Williams et al., 1990) for 45 cycles in a gradient thermal-cycler (Brinkman instruments Inc., Westbury, N.Y.). Each cycle consisted of $60 \mathrm{~s}$ at $94^{\circ} \mathrm{C}, 60 \mathrm{~s}$ at $35^{\circ} \mathrm{C}$, and $90 \mathrm{~s}$ at $72^{\circ} \mathrm{C}$. Fragments were separated by gel electrophoresis on a $1.5 \%$ agarose gel at $100 \mathrm{~V}$ for $1 \mathrm{~h}$ in $1 \times$ TrisAcetic Acid-EDTA (TAE) buffer. Gel banding patterns were visualized under ultraviolet light after staining with ethidium bromide $\left(4 \mathrm{ng} \cdot \mathrm{mL}^{-1}\right)$ using a Gel Doc 2000 system and pictures were digitally recorded with Quantity One software (Bio-Rad Laboratories, Hercules, Calif.). Ge- netic differences were scored based on the presence or absence of polymorphisms generated by 31 primers for the 79 cultivars tested. The 49 polymorphisms scored represented RAPD bands that were clear and repeatable.

Data analysis. Genetic similarities were estimated from the genotypic data using a simple matching coefficient as described by (Sneath and Sokal, 1973). The 79 cultivars were clustered based on a matrix of genetic similarities using the clustering algorithm with GenStat 5.0 software. The dissimilarity index measured the mean genetic distance between a cluster and all other clusters.

\section{Results}

In total, 49 polymorphisms were identified based on amplification of the DNAs of the 79

Table 2. Estimated size and frequency of polymorphisms generated by primers between the 79 common bean varieties.

\begin{tabular}{|c|c|c|}
\hline $\begin{array}{l}\text { Primer } \\
\text { no. }\end{array}$ & $\begin{array}{c}\text { Frequency } \\
(\%)\end{array}$ & $\begin{array}{c}\text { Polymorphism } \\
\text { length (bp) }\end{array}$ \\
\hline${ }^{2} \mathrm{UBC} 101$ & 28.8 & 825 \\
\hline UBC 102 & 48.8 & 850 \\
\hline UBC 104 a & 82.5 & 825 \\
\hline UBC 104 b & 87.5 & 650 \\
\hline UBC 106 & 85.0 & 500 \\
\hline UBC 110 a & 12.5 & 1500 \\
\hline UBC $110 b$ & 76.3 & 610 \\
\hline UBC 111 & 82.5 & 425 \\
\hline UBC 112 a & 16.3 & 1650 \\
\hline UBC $112 b$ & 56.3 & 1500 \\
\hline UBC 114 & 83.8 & 1400 \\
\hline UBC 119 & 86.3 & 110 \\
\hline UBC 120 a & 53.8 & 1625 \\
\hline UBC $120 \mathrm{~b}$ & 23.8 & 1500 \\
\hline UBC 132 & 30.0 & 1600 \\
\hline UBC 134 a & 82.5 & 1700 \\
\hline UBC 134 b & 5.0 & 600 \\
\hline UBC 137 & 78.8 & 1300 \\
\hline UBC 145 a & 53.8 & 1400 \\
\hline UBC $145 b$ & 70.0 & 750 \\
\hline UBC 146 a & 78.8 & 1400 \\
\hline UBC 146 b & 57.5 & 1100 \\
\hline UBC $146 \mathrm{c}$ & 26.3 & 500 \\
\hline UBC 147 & 47.5 & 1050 \\
\hline UBC 148 a & 81.3 & 2000 \\
\hline UBC 148 b & 57.5 & 1650 \\
\hline UBC 150 a & 15.0 & 1250 \\
\hline UBC $150 \mathrm{~b}$ & 55.0 & 1050 \\
\hline UBC $150 \mathrm{c}$ & 17.5 & 675 \\
\hline UBC 151 & 48.8 & 725 \\
\hline UBC 154 & 38.8 & 1500 \\
\hline UBC 156 & 92.5 & 1100 \\
\hline UBC 157 a & 50.0 & 800 \\
\hline UBC $157 \mathrm{~b}$ & 12.5 & 550 \\
\hline UBC 158 & 51.3 & 1500 \\
\hline UBC 165 a & 45.0 & 1400 \\
\hline UBC $165 b$ & 46.3 & 1200 \\
\hline UBC 165 c & 28.8 & 825 \\
\hline UBC 174 & 78.8 & 850 \\
\hline UBC 175 & 86.3 & 1350 \\
\hline UBC 177 & 26.3 & 1450 \\
\hline UBC 185 a & 87.5 & 1625 \\
\hline UBC $185 b$ & 5.0 & 1150 \\
\hline UBC 186 a & 27.5 & 2000 \\
\hline UBC $186 b$ & 62.5 & 1690 \\
\hline UBC $186 \mathrm{c}$ & 91.3 & 750 \\
\hline UBC 194 a & 81.3 & 650 \\
\hline UBC 194 b & 10.0 & 550 \\
\hline UBC 199 & 43.8 & 1450 \\
\hline
\end{tabular}

${ }^{2} \mathrm{UBC}=$ University of British Columbia. common bean cultivars (Table 2). The range of frequencies of these polymorphisms varied from $5 \%$ to $92.5 \%$ and provided molecular information for determining genetic similarities of the cultivars. A cluster analysis was performed based on the 49 polymorphic loci and used to generate a dendogram (Fig. 1), which formed six major clusters, one of which (cluster [3]) contained a single variety 'Sprite'. The dendogram separated the two S-type phaseolin dry bean cultivars from the Mesoamerican gene pool ['Aurora' (small white) and 'Seafarer' (navy bean)] at the 0.75 dissimilarity index (cluster [1]). Most small sieve whole bean cultivars were separated at the 0.62 dissimilarity index (cluster [2]). The two romano beans shared the same cluster along with four large sieve cultivars. The majority of large sieve cultivars were clustered together (clusters [4], [5], and [6]). Certain 


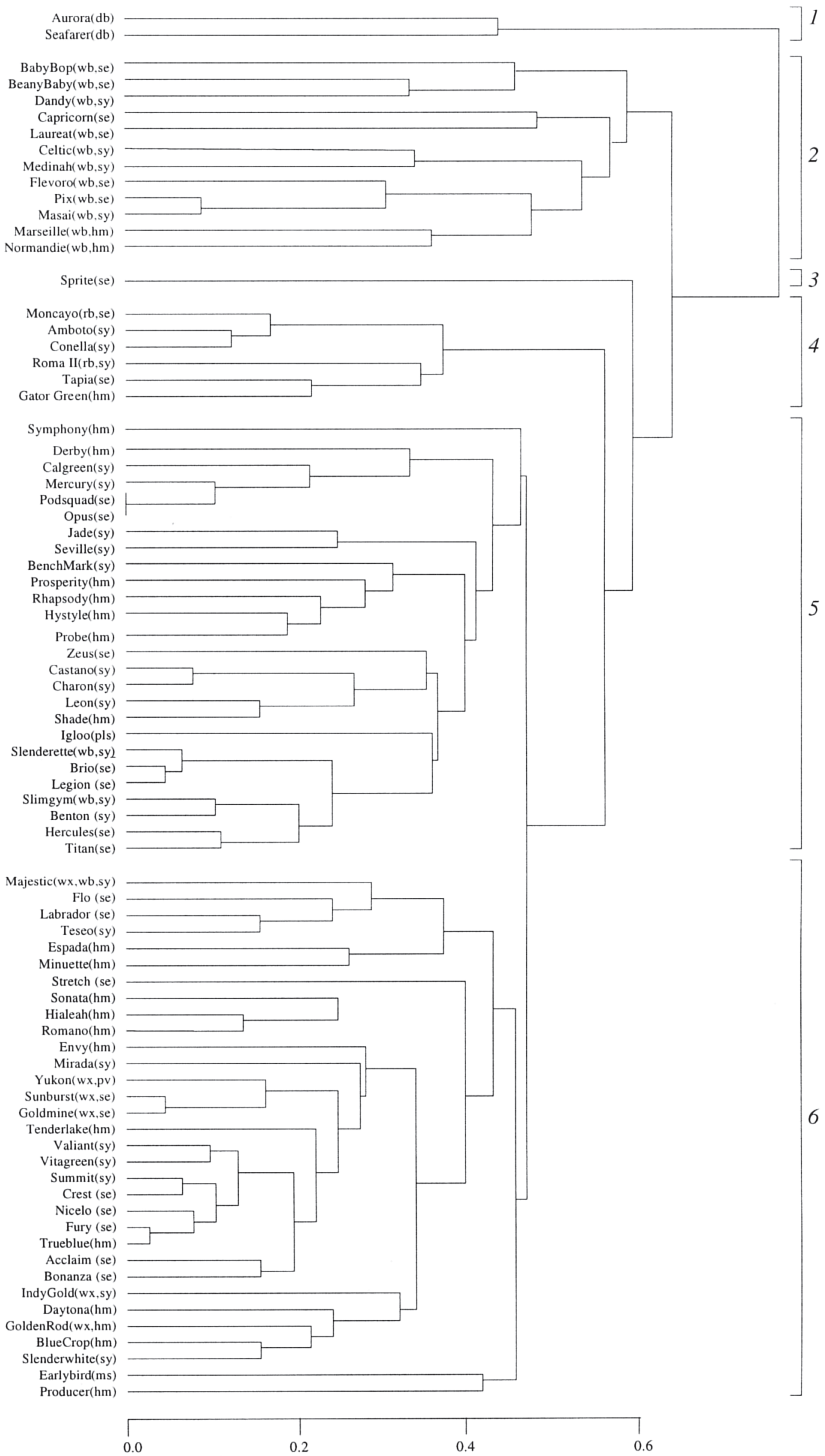

Fig. 1. Dendrogram showing genetic dissimilarities of 79 common bean varieties and formation of six clusters; $w b=$ whole bean, $\mathrm{wx}=$ wax bean, $\mathrm{db}=$ dry bean, $\mathrm{rb}=$ romano bean, se $=$ Seminis vegetable seeds, $\mathrm{hm}=$ Harris Moran vegetable seeds, sy $=$ Syngenta vegetable seeds, pls $=$ Pure Line seeds, $p v=$ Pop Vriend. 
classes had high levels of genetic similarity, such as, the wax beans 'Yukon', 'Sunburst', and 'Goldmine'. The only cultivars that could not be separated based on the 49 polymorphisms were 'Podsquad' and 'Opus', which are both marketed by Seminis vegetable seeds and have similar horticultural characteristics.

\section{Discussion}

Snap beans are common beans developed primarily from the Andean (T-type) gene pool (Gepts and Bliss, 1985). This study evaluated genetic variation between cultivars and classes of snap beans. The two dry bean cultivars that were included in this study were clearly separated from the snap bean cultivars based on genetic dissimilarity. The study was also able to differentiate the majority of the small-sieve genotypes into a single cluster that contained only one larger-sieve type ('Capricorn'). It is likely that these cultivars share a common pedigree that is more closely associated with the two dry bean cultivars than the majority of snap bean cultivars. This suggests that many of the small-sieve cultivars have a higher genetic similarity to the dry bean cultivars developed out of the Middle American gene pool, and may be based partly on hybridizations to germplasm from this gene pool. Determination of phaseolin type of these whole bean cultivars would be informative in determining whether they contain Middle American material in their backgrounds. The six wax beans evaluated were not separated from the majority of snap bean cultivars, suggesting that this phenotype does not involve a high degree of genetic dissimilarity. However, the wax beans were all closely related, with 'Yukon', 'Sunburst' and 'Goldmine' forming a tight cluster, and 'IndyGold' and 'Golden Rod' showing very close similarity. These associations are probably related to pedigree as are the associations of many of the snap beans in this study. The small-sieve wax bean 'Majestic' was less closely related and was clearly identified from all other cultivars tested with a genetic dissimilarity of 0.28 .

These results identified common molecular polymorphisms in different classes of snap beans that highlight similarities in their breeding pedigrees. The results also provide information to enable wide crosses of cultivars while maintaining the intended pod type. The use of RAPD markers in this study has demonstrated the benefits of molecular markers in identifying genetic diversity with the snap bean market class. The information documented can also be used in determining similarity of cultivars developed by different breeders/seed companies, in determining seed purity of seed lots and differentiating cultivars if errors have been made in distribution.

This research will help breeders when choosing parents for use in crosses, and will help to exploit the genetic variation that exists in snap bean germplasm. The evaluation of plant introductions at germplasm repositories using these markers would also help in determining duplications and the extent of genetic diversity represented in the common bean core collection.

\section{Literature cited}

Alzate-Marin, A.L., G.S. Baia, S.M. Filho, T.J. de Paula, Jr., C.S. Sediyama, E.G. de Barros, and M.A. Moreira. 1996. Use of RAPD-PCR to identify true hybrid plants from crosses between closely related progenitors. Braz. J. Genet. 19:621-623.

Bartish, I.V., L.P. Garkava, K. Rumpunen, and H. Nybom. 2000. Phylogenetic relationships and differentiation among and within populations of Chaenomeles Lindl. (Rosaceae) estimated with RAPDs and isozymes. Theor. Appl. Genet. 101:554-563.

Bautista, R., R. Crespillo, F.M. Canovas, and N.G. Claros. 2002. Identification of olive-tree cultivars with SCAR markers. Euphytica 129:33-41.

Beebe, S.E., I. Ochoa, P. Skroch, J. Nienhuis, and J. Tivang. 1995. Genetic diversity among common bean breeding lines developed for Cental America. Crop Sci. 35:1178-1183.

Boodley, J.W. and R. Sheldrake, Jr. 1982. Cornell peat-lite mixes for commercial plant growing. N.Y. Agr. Expt. Sta. Agr. Info. Bul. 43.

Davis, J. and J.R. Myers. 2002. Phylogentic analysis of snap beans using RAPD markers. Annu. Rpt. Bean Impr. Coop. 45:16-17.

Doyle, J. and J. Doyle. 1990. Isolation of plant DNA from fresh tissue. Focus 12:13-15.

Gaitan-Solis, E., M.C. Duque, K.J. Edwards, and J. Tohme. 2002. Microsatellite repeats in common bean (Phaseolus vulgaris): isolation, characterization and cross-species amplification in Phaseolus ssp. Crop Sci. 42:2128-2136.

Gepts, P. and F.A. Bliss. 1985. $F_{1}$ hybrid weakness in the common bean: Differential geographic origin suggests two gene pools in cultivated bean germplasm. J. Hered. 76:447-450.

Gepts, P., T.C. Osborn, K. Rashka, and F.A. Bliss.
1986. Phaseolin protein variability in wild forms and landraces of the common bean (Phaseolus vulgaris): Evidence for multiple centers of domestication. Econ. Bot. 40:451-468.

Graham, G.C., R.J. Henry, and R.J. Redden. 1994. Identification of navy bean cultivars using random amplification of polymorphic DNA. Austral. J. Expt. Agr. 34:1173-1176.

Haley, S.D., P.N. Miklas, L. Afanador, and J.D. Kelly. 1994. Random amplified polymorphic DNA (RAPD) marker variability between and within gene pools of common bean. J. Amer. Soc. Hort. Sci. 119:122-125.

Johns, M. A., P. W. Skroch, J. Nienhuis, P. Hinrichsen, G. Bascur, and C. Munoz-Schick. 1997. Gene pool classification of common bean landraces from Chile based on RAPD and morphological data. Crop Sci. 37:607-613.

Koenig, R., S. P. Singh, and P. Gewpts. 1990. Novel phaseolin types in wild and cultivated common bean (Phaseolus vulgaris Fabaceae). Econ. Bot. 44:44-50.

Lu, J., M.R. Knox, M.J. Ambrose, J.K. Brown and T.H. Ellis. 1997. Comparative analysis of genetic diversity in pea assessed by RFLPand PCR-based methods. Theor. Appl. Genet. 93:1103-1111.

Machado, G.F., J.B. Dos Santos, G.H. Nunes, and J.M. Duarte. 2000. Efficiency of genetic distance based on RAPD markers for choosing parents of common bean. J. Genet. Breed. 5:251-258.

Metais, I., C. Aubry, B. Hamon, and R. Jalouzot. 2000. Description and analysis of genetic diversity between commercial bean lines (Phaseolus vulgaris L.). Theor. Appl. Genet. 101:1207-1214

Singh, S.P., R. Nodari, and P. Gepts. 1991. Genetic diversity in cultivated common bean. I. Allozymes. Crop Sci. 31:19-23.

Skroch, P.W., J. Tiang, and J. Nienhuis. 1992. Analysis of genetic relationships using RAPD marker data, p. 26-30. In: Applications of RAPD technology to plant breeding. Joint Plant Breeding Symp. Ser., CSSA, ASHS, AGA, 1 Nov. 1992, Minneapolis, Minn.

Skroch, P. W., J. Nienhuis, S. Beebe, J. Tohme, and F. Pedraza. 1998. Comparison of Mexican common bean (Phaseolus vulgaris L.) core and reserve germplasm collections. Crop Sci. 38:488-496.

Sneath, P.H.A. and R.R. Sokal. 1973. Numerical taxonomy. W.H. Freman Co., San Fransisco.

Steiger, D.L., C. Nagai, P.H. Moore, C.W. Morden, R.V. Osgood, and R. Ming. 2002. AFLP analysis of genetic diversity within and among Coffea arabica cultivars. Theor. Appl. Genet. 261:627-634.

Williams, S., A. Kubelik, K. Livak, J. Rafalski, and S. Tingey. 1990. DNA polymorphisms amplified by arbitrary primers are useful as genetic markers. Nuc. Acids Res. 18:6531-6535. 